\title{
PENERAPAN STRATEGI "ALIS PAMAN PANJANG" UNTUK MENINGKATAN KETERAMPILAN MENULIS PANTUN KELAS V SD NEGERI SUGIHAN O3 SEMESTER 1 TAHUN PELAJARAN 2019/ 2020
}

\author{
Efa Widyastuti \\ SD Negeri Sugihan 03, Kecamatan Bendosari \\ Author Correspondence : widyastutiefa88@gmail.com
}

\begin{abstract}
Abstrak
Praktik baik ini bertujuan untuk meningkatkan keterampilan menulis pantun pada siswa kelas V SD Negeri Sugihan 03 Kecamatan Bendosari. Penggunaan strategi "Alis Paman Panjang" merupakan akronim dari "Analisis Pantun Mandiri melalui Pendampingan Berjenjang". Proses pelaksanaan strategi "Alis Paman Panjang" adalah 1) siswa menganalisis karya pantun secara mandiri, 2) menyebutkan ciri-ciri pantun berdasarkan analisis dan pengamatan, 3) menyusun potongan kertas berisi kalimat acak dari sebuah pantun, 4) melengkapi pantun yang rumpang, 5) membuat pantun berdasarkan tema tertentu. Hasil praktik baik penerapan strategi "Alis Paman Panjang" adalah meningkatnya keterampilan menulis pantun pada siswa kelas V SD Negeri Sugihan 03, Kecamatan Bendosari.
\end{abstract}

Kata kunci: alis paman panjang, keterampilan menulis, strategi, pantun

\begin{abstract}
This best practice aims to improve rhymes writing skills in fifth grade students of Sugihan 03 Elementary School in Bendosari District. The use of the "Alis Paman Panjang" strategy is an acronym from "Analisis Pantun Mandiri melalui Pendampingan Berjenjang". The process for implementing the "Alis Paman Panjang"'" strategy are 1) students analyze the work of rhymes independently, 2) mention the characteristics of rhymes based on analysis and observation, 3) compile pieces of paper containing random sentences from a rhymes, 4) complete rhymes that overlap 5) making rhymes based on certain themes. The result of the best practice of applying the "Alis Paman Panjang" strategy was the improvement of the rhymes writing skills in fifth grade students of Sugihan 03 Elementary School, Bendosari District.
\end{abstract}

Keywords: alis paman panjang, rhymes, strategy, writing skills 


\section{Pendahuluan}

Pelajaran Bahasa Indonesia pada dasarnya membutuhkan penerapan pembelajaran keterampilan berpikir tingkat tinggi. Kemampuan berpikir tingkat tinggi memerlukan strategi pembelajaran yang spesifik dan tidak dapat digunakan di situasi belajar lainnya (Ariyana, 2019). Menurut seorang ahli, keterampilan berpikir tingkat tinggi diartikan sebagai proses berpikir komplek dalam menguraikan materi, membuat kesimpulan, membangun representasi, menganalisis, dan membangun hubungan dengan melibatkan aktivitas mental yang paling dasar Resnick (dalam Ariyana, 2019).

Keterampilan bahasa meliputi keterampilan menyimak, berbicara, membaca, dan menulis. Keterampilan bahasa tersebut saling berhubungan dan mempengaruhi antara satu dengan yang lain. Keterampilan menulis dasar sudah diajarkan sejak SD kelas 1. Menulis merupakan kegiatan yang produktif karena menghasilkan suatu karya tulis yang berisi ide seseorang. Menulis adalah kegiatan komunikasi berupa penyampaian pesan secara tertulis kepada pihak lain (Azmussya'ni, 2014).

Keterampilan menulis tidak bisa didapatkan dengan begitu saja, namun perlu adanya latihan yang berulang dan teratur. Selain itu bisa juga dengan penerapan pembiasaan dalam kegiatan pembelajaran sehari-hari. Keterampilan menulis di kelas tinggi khususnya kelas $\mathrm{V}$ meliputi menulis prosa, puisi, pantun, iklan, maupun surat undangan.

Pantun jarang kita gunakan untuk berkomunikasi dalam kehidupan sehari-hari. Zaman dahulu pantun memiliki tempat yang penting dalam kehidupan masyarakat Melayu khususnya. Pantun banyak digunakan dalam permainan kana-kanak, dalam percintaan, upacara peminangan dan pernikahan, nyanyian, dan upacara adat (Fauzi, 2014). Saat ini, siswa mengenal pantun dari acara televisi misalnya film Upin dan Ipin, facebooker, atau acara lain yang menyelipkan pantun dalam penyampaiannya, iklan, majalah, koran maupun media lainnya. Selain itu, siswa mengenal pantun pun terbatas hanya pada pembelajaran bahasa Indonesia.

Pada materi pantun, dipelajari tentang jenis-jenis pantun, ciri-ciri pantun, maupun membuat pantun. Pantun terdiri atas dua bagian yaitu sampiran dan isi. Sampiran adalah dua baris pertama yang biasanya tidak punya hubungan dengan bagian kedua. Sampiran hanya digunakan untuk mengantarkan rima/ sajak agar padu dengan dua baris terakhir yang merupakan isi (Pangesti, 2015:7).

Tidak ada materi langkah-langkah khusus yang digunakan dalam membuat pantun. Pembelajaran pantun biasanya hanya mengacu pada tema. Setelah ditentukan tema, barulah pantun dibuat sesuai kreativitas masing-masing siswa. Hal inilah yang membuat siswa masih merasa kesulitan dalam membuat serta memadupadankan kalimat agar menjadi pantun yang baik.

Pada pembelajaran awal, siswa mengalami kesulitan dalam membuat pantun. Pantun yang dibuat kurang padu antara kalimat sampiran dan isi. Membuat pantun membutuhkan pemikiran yang lebih panjang karena harus dapat membuat keterkaitan pada sajak akhirnya. Selain itu, membuat pantun juga harus dapat mengaitkan isi pada kalimat sampiran maupun kalimat isi.

Berdasarkan masalah tersebut di atas, perlu adanya suatu penerapan strategi untuk membantu siswa meningkatkan keterampilan menulis pantun. Salah satu strategi yang dapat digunakan adalah strategi "Alis Paman Panjang". Strategi tersebut merupakan strategi pembelajaran pantun yang berdasarkan pada filsafat pendidikan konstruktivisme. 
Berdasarkan uraian di atas, ada dua rumusan masalah yang dikaji. Pertama, bagaimana proses pembelajaran dengan penerapan strategi "Alis Paman Panjang" dalam pembelajaran pantun siswa kelas V SD Negeri Sugihan 03. Kedua, bagaimana peningkatan keterampilan menulis pantun siswa kelas V SD Negeri Sugihan 03.

Tujuan pertama yang ingin dicapai adalah memberikan gambaran tentang proses pembelajaran dengan penerapan strategi "Alis Paman Panjang" dalam pembelajaran pantun siswa kelas V SD Negeri Sugihan 03. Tujuan kedua, meningkatkan keterampilan menulis pantun siswa kelas V SD Negeri Sugihan 03.

\section{Kajian Pustaka}

Menulis adalah salah satu cara berkomunikasi tidak langsung dengan media tulisan. Informasi, berita, curahan ide bisa disampaikan dengan menuliskannya. Menulis ialah proses mengemukakan pendapat atas dasar masukan yang diperoleh penulis dari berbagai sumber ide. Menulis merupakan kegiatan mereaksi sumber ide yang dapat berupa segala obyek yang merangsang penulis untuk menulis termasuk tulisan dari orang lain (Abidin, 2012).

Keterampilan menulis akan dapat meningkat jika dilatih secara terus menerus. Latihan dapat dilakukan dengan pembimbingan. Bimbingan adalah bantuan atau tuntutan khusus yang diberikan kepada siswa dengan memperhatikan potensi-potensi yang ada pada siswa tersebut agar dapat berkembang semaksimal mungkin Arikunto (dalam Surono, 2016). Kemampuan menulis setiap orang berbeda-beda. Beberapa faktor yang mempengaruhi keterampilan menulis seseorang antara lain pengalaman dan pembiasaan menulis. Keterampilan menulis adalah kegiatan mengomunikasikan gagasan, pikiran, dan perasaan yang dituangkan dalam bentuk tulisan dengan menggunakan bahasa yang telah dimengerti bersama tanpa harus bertatap muka secara langsung (Susanto, 2015)

Tujuan menulis yaitu untuk menyampaikan sesuatu kepada orang lain, sedangkan muatannya adalah berupa pikiran, perasaan, gagasan, pesan dan pendapat (Pramita, 2017).

Pantun berkembang di nusantara di berbagai daerah dengan istilah yang berbeda. Istilah pantun berasal dari bahasa Minangkabau "patuntun" yang berarti penuntun. Pantun dikenal dengan "paparikan" pada masyarakat Sunda, masyarakat Jawa mengenal pantun dengan istilah "parikan" (Noffitri, 2013). Pantun merupakan gubahan yang diuntai atau diikat oleh ikatan-ikatan tertentu.

Pantun terdiri atas sampiran dan isi. Pantun mementingkan rima akhir dan rumus rima itu disebut dengan abjad (ab-ab). Maksudnya, bunyi akhir baris pertama sama dengan bunyi akhir baris ketiga, dan baris kedua sama dengan baris keempat (Fauzi, 2014).

Setiap materi pelajaran membutuhkan strategi yang sesuai agar materi dapat diterima dan dimengerti dengan baik oleh siswa. Materi pantun ini belum ada panduan langkah-langkah yang memudahkan cara membuatnya. Upaya yang dilakukan guru adalah dengan mencari dan menerapkan strategi yang sesuai.

Penerapan strategi "Alis Paman Panjang" ini merupakan salah satu upaya meningkatkan keterampilan menulis pantun bagi siswa. Strategi "Alis Paman Panjang" merupakan akronim dari analisis pantun mandiri melalui pembimbingan berjenjang. Strategi yang diterapkan ini berlandaskan kontruktivisme. Siswa belajar dari hal-hal yang mudah dengan panduan kemudian diarahkan agar mampu menyelesaikannya secara mandiri. 


\section{Metodologi Penelitian}

Penelitian ini merupakan best practice dengan penerapan strategi "Alis Paman Panjang" dalam meningkatkan keterampilan menulis pantun. Strategi ini merupakan salah satu strategi yang merupakan bagian dari model pembelajaran active learning.

Subjek dalam penelitian ini adalah siswa kelas V SD Negeri Sugihan 03 tahun pelajaran 2019/ 2020. Tempat yang digunakan di kelas V SD Negeri Sugihan 03 Kecamatan Bendosari Kabupaten Sukoharjo. Siswa kelas V berjumlah 21 orang siswa. Penelitian ini dilaksanakan pada bulan Oktober tahun 2019.

Beberapa langkah yang ditempuh dalam kegiatan pembelajaran dengan penerapan strategi "Alis Paman Panjang" yaitu perencanaan, pelaksanaan, evaluasi, dan tindak lanjut. Perencanaan dilaksanakan dengan menyusun langkah pembelajaran serta menyiapkan perlengkapan pembelajaran yang dibutuhkan (alat, bahan, maupun media). Pelaksanaan dilaksanakan dengan menerapkan strategi "Alis Paman Panjang”. Evaluasi dan tindak lanjut dilaksanakan dengan pengamatan selama pembelajaran berlangsung, serta memberikan tes tertulis, dan diakhiri dengan refleksi pelaksanaan kegiatan belajar.

Tekhnik pengambilan data dalam penelitian ini dilakukan dengan dua cara. Pertama, berupa dokumentasi hasil kegiatan siswa disertai foto. Dokumentasi ini membantu pengamatan beberapa kegiatan yang sebelumnya belum dapat diamati secara mendalam. Kedua, tes tertulis yang digunakan untuk mengukur sejauh mana peningkatan keterampilan menulis siswa setelah diterapkan strategi "Alis Paman Panjang"

Data dari dokumentasi, pengamatan, maupun tes tertulis yang telah diperoleh kemudian dianalisis. Hasil analisis inilah yang nanti akan menjadi bahan kesimpulan pelaksanaan penerapan strategi "Alis Paman Panjang" dalam pembelajaran menulis pantun.

\section{Hasil dan Pembahasan}

Kegiatan pembelajaran diawali dengan pembuatan perencanaan, pelaksanaan, serta evaluasi dan tindak lanjut. Adapun penjabaran masing-masing langkah adalah sebagai berikut.

a. Perencanaan

Ada beberapa tahapan yang dilakukan dalam perencanaan penerapan strategi

"Alis Paman Panjang" untuk meningkatkan keterampilan menulis pantun.

1. Mengidentifikasi masalah pembelajaran tentang materi pelajaran pantun berdasarkan kegiatan pembelajaran yang sudah dilaksanakan dan hasil pembelajaran yang telah didapatkan.

2. Merencanakan tindakan yang akan dilakukan untuk mengatasi masalah yang terjadi yaitu rendahnya keterampilan menulis pantun pada siswa kelas V SD Negeri Sugihan 03 Kecamatan Bendosari.

3. Membuat RPP yang sesuai dengan perencanaan tindakan.

4. Membuat instrumen penilaian yang sesuai dengan strategi yang akan dilaksanakan.

5. Mengembangkan media yang digunakan untuk pembelajaran (power point, video pembelajaran, kertas pantun, dan lembar kerja siswa)

6. Menyusun lembar pengamatan sikap dan keterampilan menulis pantun serta rubrik penilaiannya.

b. Pelaksanaan 
Muatan Pelajaran Bahasa Indonesia di kelas V semester 1 terdapat KD pengetahuan 3.6. Menggali isi dan amanat pantun yang disajikan secara lisan dan tulis dengan tujuan untuk kesenangan. Sedangan kompetensi dasar pada keterampilan 4.6. Melisankan pantun hasil karya pribadi dengan lafal, intonasi, dan ekspresi yang tepat sebagai bentuk ungkapan diri. KD 4.6 tersebut di atas, siswa dituntut untuk dapat membuat pantun karya pribadi. Keterampilan menulis pantun sangat dibutuhkan agar siswa dapat mencapainya.

Pembelajaran biasa dilaksanakan dengan bantuan buku siswa maupun buku PR. Siswa belajar tentang ciri-ciri, jenis, dan membuat pantun. Setelah itu siswa mendapat penugasan yaitu membuat pantun sesuai tema yang disepakati bersama. Tema yang diambil adalah hasil kesepakatan dengan harapan siswa akan lebih mudah mendapatkan ide dengan tema yang mereka kehendaki.

Berdasarkan hasil pengamatan, siswa masih banyak yang mengalami kebingungan dan tidak tahu harus memulai darimana membuat pantun. Dari 21 siswa, hanya 5 orang siswa yang berhasil membuat pantun yang padu sesuai dengan tema yang ditentukan. Sisanya sebanyak 16 siswa belum bisa menuliskan pantun yang ditugaskan.

Guru menanyakan kesulitan apa yang dihadapi sehingga siswa tidak bisa membuat/ menyelesaikan pantunnya. Mayoritas siswa merasa kesulitan dan bingung bagaimana harus memulai membuat pantun.

Adanya beberapa kesulitan yang dialami oleh siswa ini, guru mengupayakan sebuah strategi "Alis Paman Panjang" atau analisis pantun mandiri melalui pendampingan berjenjang. Adapun langkah-langkah yang dilakukan adalah sebagai berikut.

1) Alis Paman (analisis pantun mandiri)

Pada tahap ini, siswa menyaksikan tayangan video pembelajaran tentang pantun. Dari pantun yang ada pada tayangan video, siswa mencatat pantun yang disampaikan. Setelah pantun dicatat, secara berkelompok siswa berdiskusi tentang ciri-ciri pantun tersebut. Setelah berdiskusi, siswa menyampaikan hasil diskusi tentang ciri-ciri pantun secara bergantian.

2) Panjang (pendampingan berjenjang)

Pendampingan berjenjang ini dilakukan dengan memberi stimulus siswa belajar membuat pantun dari hal yang mudah ke yang lebih sulit, yaitu membuat pantun secara mandiri. Langkah pertama, siswa diberi 4 potongan kertas yang berisi penggalanpenggalan pantun. Kedua, secara berkelompok siswa menyusun kertas tersebut agar menjadi pantun yang runtut dan padu. Bagi kelompok yang sudah selesai bisa menyanyikan yel-yel kelompoknya dan menyampaikan hasil diskusi kelompok. Setelah menyampaikan hasil diskusi, siswa dibimbing untuk diskusi secara klasikal tentang kebenaran urutan pantun. Kelompok yang maju akan mendapat nilai bintang yang ditempel di papan tulis.

Kegiatan yang sama dilakukan berulang hingga 3 pantun. Setelah semua kelompok dapat menyusun urutan dengan tepat, langkah keempat adalah setiap kelompok diberi pantun yang masih rumpang dan diminta untuk melengkapi. Kelompok yang sudah berhasil dapat menyampaikan hasil diskusinya ke depan kelas. Kemudian jawaban dibahas secara bersama-sama.

Langkah kelima, siswa membuat pantun berdasarkan tema yang disepakati dengan acuan waktu tertentu. Kelompok yang sudah selesai menyanyikan yel-yel kelompok 
kemudian membacakan pantun karyanya. Kelompok yang mendapat bintang paling banyak akan mendapatkan hadiah dari guru.

c. Evaluasi dan tindak lanjut

Evaluasi siswa dilaksanakan secara mandiri dengan menyusun kalimat suatu pantun yang diacak, melengkapi kalimat pantun yang rumpang, kemudian membuat pantun secara utuh.

Hasil yang diperoleh dari penerapan strategi "Alis Paman Panjang" adalah dari 21 siswa sebanyak 6 anak mendapat nilai 100, 10 anak mendapat nilai 90, 3 anak mendapat nilai 80, dan nilai 70 sebanyak 2 anak. Nilai rata-rata kelas adalah 89,52.

Adapun hasil evaluasi disajikan dalam grafik berikut ini:

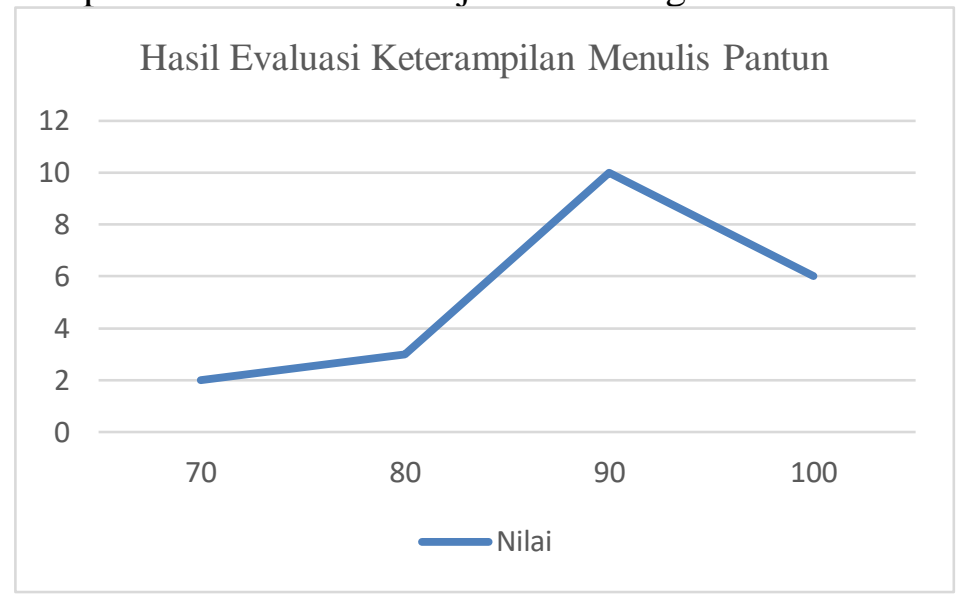

Grafik 1 Hasil evaluasi keterampilan menulis pantun

Siswa yang mendapat nilai 100 adalah siswa yang dapat menyusun kalimat pantun yang acak menjadi pantun yang runtut dan padu, melengkapi pantun yang rumpang, dan membuat pantun secara mandiri. Bagi siswa yang mendapat nilai kurang dari 100, ada yang salah dalam menyusun pantun, tidak tepat dalam melengkapi pantun rumpang, adapula yang masih kurang padu dalam membuat pantun secara mandiri.

Dari hasil observasi yang dilakukan, mayoritas siswa menyatakan bahwa lebih mudah membuat pantun secara mandiri dari pada melengkapi kalimat pantun yang rumpang. Untuk melengkapi pantun yang rumpang, siswa merasa terikat dengan sajak akhir pada pantun yang sudah ada. Namun, apabila membuat secara mandiri, siswa lebih leluasa memadupadankan kalimat yang sesuai. Secara keseluruhan, siswa telah terampil membuat pantun secara mandiri.

Bentuk tindak lanjut dari keberhasilan siswa dalam membuat pantun secara mandiri ini adalah membukukan karya siswa dalam sebuah buku ber-ISBN. Judul buku kumpulan pantun tersebut adalah "Sekoci" dengan nomor ISBN 9-786237679028. 


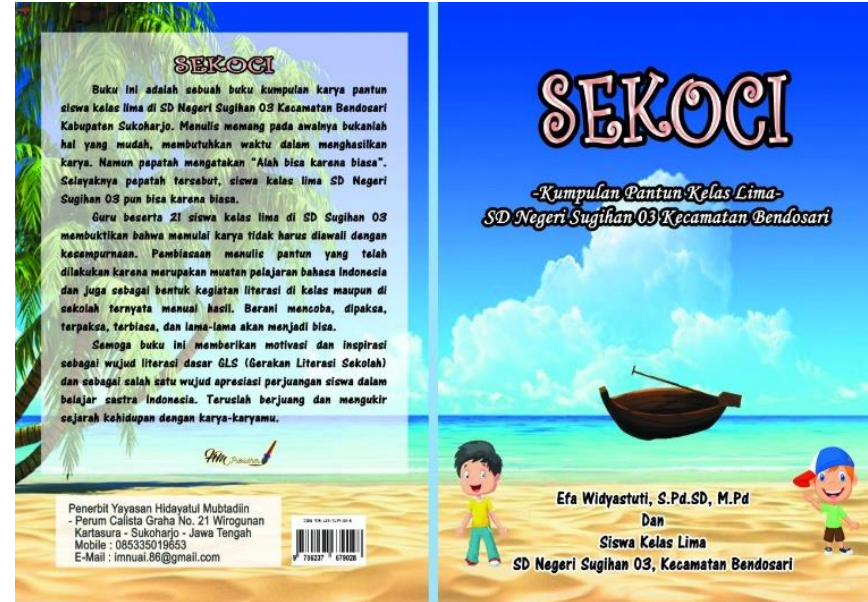

Gambar 1 Buku kumpulan pantun siswa kelas V

Keterampilan menulis pantun pada siswa dapat berkembang lebih baik ketika diterapkan strategi "Alis Paman Panjang". Selain itu perlu adanya tindak lanjut dari hari ke hari melalui latihan terus menerus serta mengembangkan ide melalui tema yang berbeda agar keterampilan siswa lebih meningkat.

\section{Simpulan dan Saran}

Berdasarkan penerapan strategi "Alis Paman Panjang” pada materi menulis pantun, dapat disimpulkan: 1. Proses pembelajaran dengan penerapan strategi "Alis Paman Panjang" antara lain 1) siswa menganalisis karya pantun secara mandiri, 2) menyebutkan ciri-ciri pantun berdasarkan analisis dan pengamatan, 3) menyusun potongan kertas berisi kalimat acak dari sebuah pantun, 4) melengkapi pantun yang rumpang, 5) membuat pantun berdasarkan tema tertentu. Kesimpulan yang kedua, Penerapan strategi "Alis Paman Panjang" dapat meningkatkan keterampilan menulis pantun siswa kelas V SD Negeri Sugihan 03 Kecamatan Bendosari.

Berdasarkan simpulan dapat diberikan saran-saran sebagai berikut: 1) guru perlu menemukan strategi yang tepat dalam mengajarkan materi tertentu agar siswa dapat lebih memahami dan mampu menerapkan ilmu yang dipelajari, 2) pembelajaran keterampilan berbahasa perlu adanya latihan dan pembiasaan agar keterampilan berbahasa dapat berkembang dan menigkat, 3) guru perlu memberikan teladan dalam melatih keterampilan menulis siswa sebagai salah satu bentuk motivasi, 4) budaya literasi di kelas dan sekolah perlu dikembangkan dan dibudayakan untuk mendukung keterampilan menulis pada siswa.

\section{Daftar Pustaka}

Abidin, Yunus. (2012). Pembelajaran Bahasa Berbasis Pendidikan Karakter. Bandung: Refika Aditama

Ariyana, Yoki, dkk. (2019). Buku Pegangan Pembelajaran Berorientasi pada Keterampilan Berpikir Tingkat Tinggi. Jakarta: Kemdikbud RI

Azmussya'ni dan Muhammad N.W. (2014). Peningkatan Keterampilan Menulis Menggunakan Pendekatan Proses dengan Media Gambar di SDN 3 Sakra. Jurnal Prima Edukasi, Vol. 2. HIm 2

Fauzi, M. Miftah. (2014). Kamus Leb\ngkap Pantun Indonesia. Jakarta; Publishing Langit 
Noffitri, Kiki. $\quad$ (2013). $\quad$ Makalah Pantun. https://kikinoffitri.blogspot.com/2013/09/makalah-pantun.html diunduh di Sukoharjo 1 Desember 2019.

Pangesti, Mutia Dwi. (2015). Buku Pintar Pantun dan Berbahasa Indonesia. Jakarta: Pustaka Nusantara Indonesia

Pramita, P.A. (2017). Tingkatkan Keterampilan Menulis Sekolah Dasar Melalui Asessmen Portofolio. https://www.researchgate.net/publication/315092920_TINGKATKAN_KETERAM PILAN_MENULIS_SISWA_SEKOLAH_DASAR_MELALUI_ASESSMEN_PO RTOFOLIO diunduh di Sukoharjo, 5 Desember 2019

Sugiarto, Eko. (2009). Mengenal Pantun dan Puisi Lama: Pantun, Karmina, Syair, Gurindam, Seloka, dan Talibun. Jakarta: Pustaka Widyatama.

Surono, A.A. (2016). Peningkatan Keterampilan Menulis Cerpen melalui Media Berita dengan Metode Latihan Terbimbing pada Siswa Kelas IX F SMP Negeri 1 Jiwan Kab. Madiun Tahun Pelajaran 2013/2014. https://jurnalbioma.blogspot.com/2016/09/peningkatan-keterampilan-menuliscerpen.html diunduh di Sukoharjo, 5 Desember 2019

Susanto, Hadi. (2015). Pembelajaran Menulis Pantun. https://bagawanabiyasa.wordpress.com/2015/12/29/pembelajaran-menulis-pantun/ diunduh di Sukoharjo, 5 Desember 2019 